\title{
Eldres erfaringer med utskrivning fra sykehus
}

\section{Christina Foss}

Professor

Avdeling for sykepleievitenskap, Institutt for samfunn og helse, Universitetet i Oslo

\section{Tor Inge Romøren}

Professor

Dag Hofoss

Professor

\section{Line Kildal Bragstad}

Stipendiat

Seksjon for forskning og utdanning, Geriatrisk avdeling, Oslo universitetssykehus og Avdeling for sykepleievitenskap, Universitetet i Oslo

\section{Marit Kirkevold}

Sykepleier og professor

Avdeling for sykepleievitenskap, Institutt for helse og samfunn, Det medisinske fakultet, Universitetet i Oslo

\begin{tabular}{|l|l|l|l|}
\hline Eldre Informasjon Intervju Pasient \\
\hline
\end{tabular}

Sykepleien Forskning 20127 (4) (324-333)

DOI: 10.4220/Sykepleienf.2012.0154

\section{Sammendrag}

Bakgrunn: Utskrivning av de eldste pasientene fra sykehus til kommunale tjenester er et aktuelt tema. Hvordan eldre selv erfarer denne prosessen, har vært lite studert.

Hensikt: Beskrive eldre pasienters erfaringer med de tjenester de har fått under sykehusoppholdet som forberedelse til utskrivelse til hjem eller sykehjem. 
Metode: Data er innsamlet gjennom personlig intervju av 142 pasienter utskrevet til hjemmet og 188 utskrevet til korttids- eller langtidsopphold på sykehjem i perioden 20072009. Gjennomsnittsalderen for pasientene i unders $\varnothing$ kelsen var 85,8 år. Artikkelen presenterer både pasientenes svar på preformulerte spørsmål og frie kommentarer.

Resultater: Respondentene fremsto med klare meninger og preferanser og ga uttrykk for at de ønsket å bli hørt. De oppga mangler ved både medvirkning, informasjon og opplæring. Hver fjerde pasient oppga at de overhodet ikke fikk fortalt personalet hva de selv mente var viktig for at de skulle kunne klare seg etter utskrivelse. Over halvparten oppga at de hadde fått liten eller ingen informasjon om virkning eller bivirkning av medikamenter. Svært få oppga å ha hatt en utskrivningssamtale. Av dem som var utskrevet direkte til hjemmet, oppga 15,4 prosent at de ble skrevet ut til tomt hus.

Konklusjon: Sykehuset fyller ikke sin del av det «sømløse pasientforløpet».

\section{Innledning}

Mennesker som er 80 år eller eldre utgjør knapt fem prosent av befolkningen, men de genererer vel 20 prosent av liggedagene i somatiske sykehus (1). I utskrivningsfasen kan denne pasientgruppen oppleve en rekke utfordringer, som for eksempel bivirkninger av nye medikamenter (2), svimmelhet med $\varnothing \mathrm{kt}$ risiko for fallskader (3), økt angst eller depresjon (4), smerter, fatigue og nedsatt appetitt (5) samt nedsatt bevegelighet og derved ofte også $\varnothing \mathrm{kt}$ sosial isolasjon $(4,6)$. Manglende ivaretakelse av gamle menneskers sammensatte og komplekse behov etter utskrivning fra sykehus er en sentral årsak til reinnleggelser (7-10) eller innleggelse i sykehjem (11).

Datagrunnlaget i denne artikkelen skriver seg fra en delundersøkelse i et større prosjekt - «Pasienter på flyttefot», finansiert av Norges forskningsråd. Prosjektet unders $\varnothing$ ker sider ved overføringen av eldre pasienter fra sykehus til kommunale tjenester. I denne artikkelen er fokus på de eldres egne erfaringer med utskrivningsfasen av sykehusopphold. Pasienterfaringer er i dag etablert som én av flere kilder til kvalitetsforbedring innen helsevesenet. Få studier har likevel eksplisitt benyttet de eldres egne erfaringer som kilde til innsikt. En dagsaktuell debatt er knyttet til utfordringer med å finne fram til tiltak som er rettet inn mot helheten $\mathrm{i}$ pasientens behov, også når disse går på tvers av forvaltningsnivåer. En slik innfallsvinkel stiller krav til at pasientrollen og pasientenes erfaringer trekkes inn og tillegges vekt. 
Kunnskap om pasientenes tilstand kan si oss noe om hvilke krav som stilles til helsetjenester til eldre i utskrivningsfasen. Pasientenes egne erfaringer på dette feltet kan si oss noe om i hvilken grad sykehusene, i brukernes $\varnothing y n e$, fyller sin funksjon som gode tilretteleggere for optimal mestring etter sykehusoppholdet. Hensikten med artikkelen er å beskrive:

1. Hva kjennetegner denne eldste gruppen av sykehuspasienter?

2. Hvordan erfarer de tjenestene de har fått under sykehusoppholdet som forberedelse til utskrivelse?

\section{Metode og materiale}

I denne spørreskjemaunders $\varnothing$ kelsen er data fra pasienter innsamlet i personlige intervjuer to til tre uker etter utskrivelse fra sykehuset, enten hjemme hos pasientene eller på et sykehjem de var utskrevet til. Pasientene ble rekruttert, enten av kommunens koordinator eller leder $\mathrm{i}$ hjemmesykepleietjenesten, eller av avdelingssykepleiere ved sykehjemmene. Det ble rekruttert pasienter utskrevet fra 14 ulike sykehus i Norge. Pasientene bodde i 53 kommuner eller bydeler i Akershus, Oppland, Agder, Nord-Trøndelag og Troms, samt to bydeler i Oslo, stratifisert etter størrelse (4000 innbyggere, 4-13000 og 18000). Inklusjonskriteriet var at pasientene hadde vært innlagt på sykehuset fra eget hjem, var 80 år eller eldre og hadde ligget minimum to netter på sykehuset. Rekruttererne, som alle var erfarne sykepleiere innen eldreomsorg, vurderte pasientene. De pasientene som ble vurdert å være for fysisk eller kognitivt svekket til å kunne gi et reelt informert samtykke ble ikke inkludert. Unders $\varnothing$ kelsen ble før oppstart forelagt og godkjent av Regional komité for medisinsk og helsefaglig forskningsetikk (REK). I samråd med REK ble det, av etiske grunner, ikke foretatt noen formell testing av respondentenes kognitive funksjon (Prosjektnummer i REK: 17078). 
En litteraturgjennomgang av eksisterende instrumenter viste at selv om utskrivning av eldre og kronisk syke ganske unisont er beskrevet som et problemfelt i litteraturen, var få instrumenter tilgjengelig. Det var heller ingen referanser som kunne indikere at de ulike instrumentene var konstruert på bakgrunn av erfaringer fra tidligere instrumenter. På bakgrunn av kvalitative intervjuer med eldre pasienter (12), identifiserte vi fire områder som viktige for den eldre pasient: Utskrivningstidspunkt, faktorer ved kommunehelsetjenesten, bruk av medikamenter og sist, men ikke minst hvordan praktiske problemer skulle $1 \varnothing$ ses. Videre konkluderte gjennomgangen at til tross for at medvirkning har vist seg å være viktig for eldres mestring, målte eksisterende instrumenter grader av informasjon heller enn reell medvirkning (12). Vi utviklet derfor egne spørsmål for å unders $\varnothing$ ke pasienters og pårørendes erfaringer med sykehusopphold, informasjon og medvirkning, selve utskrivingsprosessen og tiden rett etter utskrivelse til hjemmet eller til sykehjemmet. Vi inkluderte også enkelte åpne spørsmål der det var rom for utfyllende kommentarer.

I tillegg til spørsmål om pasientenes erfaringer, var det lagt inn en seksjon med spørsmål om sosiodemografiske opplysninger og en seksjon som innhentet data om selvrapportert funksjonsnivå. I tillegg til spørsmål om pasientens syn og hørsel, benyttet vi oss av klassiske ADL-mål (13) og IADL-mål (14). Vi samlet data om fire ADL-funksjoner (kle seg, vaske seg, forflytning, spise) og tre IADL-funksjoner (handle, lett husarbeid, tyngre husarbeid). I tillegg gjorde intervjuer en enkel vurdering av hvorvidt pasienten hadde noe nedsatt hukommelse og orienteringsevne.

Ved utviklingen av spørsmålene ble det gjort fem prøveintervjuer. Erfaringene herfra ble brukt til å identifisere uklare spørsmål, spørsmål hvor de eldre syntes det var vanskelig å velge mellom de ulike svaralternativene, eller hvor respondenter hadde vansker med å huske detaljert nok fra sykehusoppholdet til å kunne svare. Intervjuere var sykepleiere som var i videreutdanning i eldreomsorg eller sykepleiere med erfaring fra eldreomsorgen. Erfaringene fra prøveintervjuene ble benyttet til en heldags opplæring av intervjuerne for å kalibrere deres spontane avkryssingspraksis, måten de skulle hjelpe pasientene til å huske (for eksempel hvor mange dager oppholdet hadde vart) og å velge de svaralternativene som de fant mest representative for sin erfaring. Det ble også utarbeidet en visuell skala som synliggjorde de fire svaralternativene (15). 
Som vist i figur 1 fikk vi i løpet av rekrutteringsperioden (oktober 2007-mai 2009) intervjuet 254 pasienter, noe som gir en svarprosent på 62. (Se figur 1.)

FIGUR 1: Oversikt over inkluderte respondenter

Pasienter som tilfredsstilte inklusjonskriteriene: alder $80+$, innlagt sykehus fra hjemmet, inneliggende minst to døgn og kognitivt i stand til å gi et reelt informert samtykke, $\mathrm{N}=413$
Pasienter som tilfredsstiller inklusjonskriteriene for øvrig, men som:

- er for fysisk eller kognitivt svekket til å gi et reellt informert samtykke, eller

- som fyllte samtlige inklusjonskriterier men som ba oss intervjue pårørende på sine vegne, $\mathrm{N}=76$

Pasienter som falt fra grunnet forverret

helsetilstand, $\mathrm{N}=14$

Pasienter som samtykket til deltagelse, $N=268$

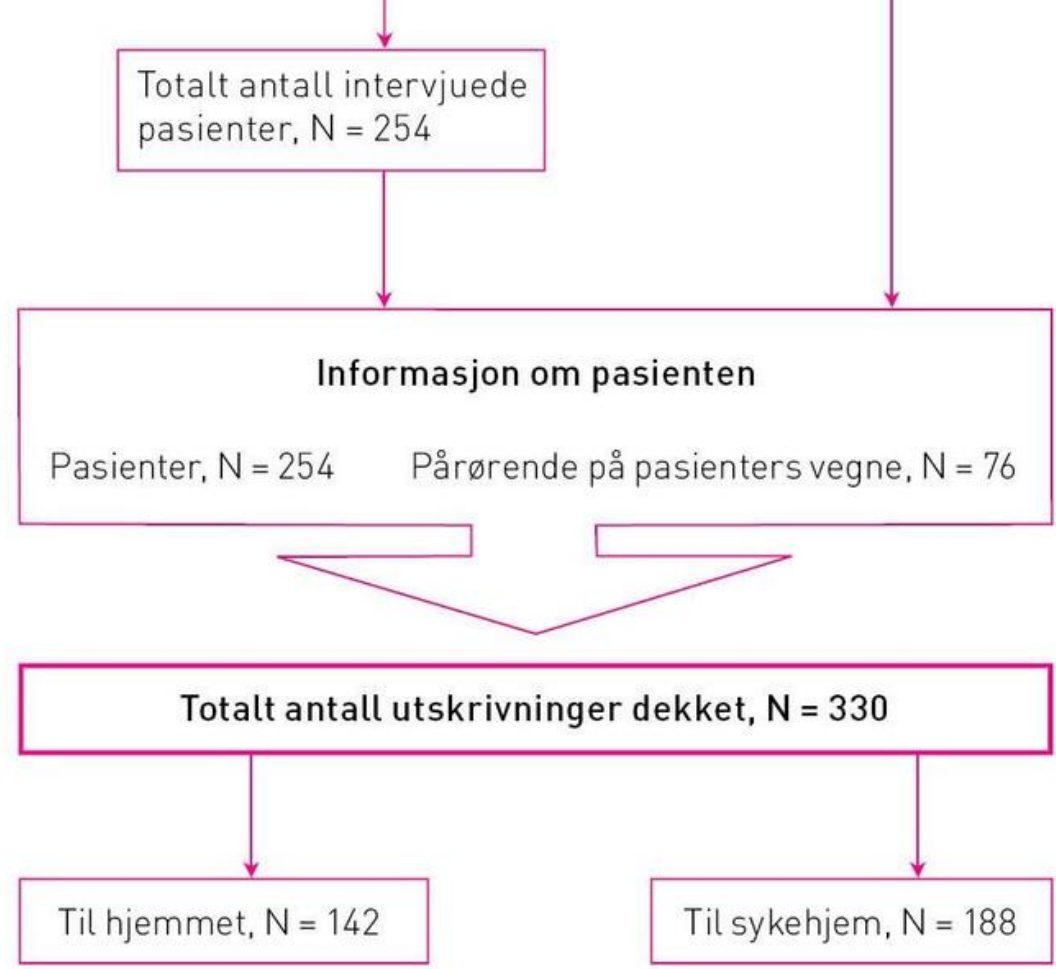


Årsak til at pasienten avslo å delta ble registrert bare i drøyt halvparten ( 53 prosent) av tilfellene. I samtlige tilfeller oppga pasientene at vedkommende ikke orket fordi hun eller han følte seg for syk eller sliten. I tillegg besvarte 76 pårørende spørsmål på pasientens vegne, slik at vi derved dekket totalt 330 utskrivelser. Et mindretall (43 prosent) av de intervjuete pasientene ble utskrevet til hjemmet, de resterende 188 pasientene (57 prosent) ble utskrevet til kort- eller langtidsopphold på sykehjem. En ukjent andel av pasientene som ble skrevet ut til sykehjem vil etter korttidsopphold skrives ut til hjemmet.

\section{Funn}

Unders $\varnothing$ kelser av eldre pasienters erfaringer er relativt sjeldne. Vi ønsket derfor å utnytte det potensialet som ligger i å løfte fram pasientens egne stemmer. I presentasjonen av funn er kvantifiserbare data kombinert med sitater fra pasientenes frie kommentarer.

Hva kjennetegner den eldre som utskrivningspasient? Gjennomsnittsalderen for pasientene i unders $\varnothing$ kelsen var 85,8 år. Nærmere 68 prosent er kvinner, og to av tre (63 prosent) hadde mistet sin ektefelle. Nær halvparten (41,3 prosent) bodde før sykehusinnleggelsen i egen, ikke tilrettelagt bolig, mens 27 prosent bodde i privat tilrettelagt bolig og 30 prosent i kommunal trygde- eller servicebolig.

Gjennomsnittlig liggetid var 13,9 døgn for sykehjemspasientene (median 10) og 10,4 for dem som reiste rett hjem (median 7).54 prosent av pasientene var utskrevet fra medisinske avdelinger, inkludert 3 prosent fra geriatrisk avdeling, 37 prosent fra kirurgiske avdelinger (inklusive 18,5 prosent fra ortopedisk avdeling) og 6 prosent fra andre avdelinger. På spørsmålet om hva respondentene ble innlagt for, varierte svarenes presisjon mye. (Se tabell 1.) 
TABELL 1: Selvrapportert innleggelsesårsak

\begin{tabular}{lll}
\hline Innleggelsesårsak & $\mathbf{N}$ & $(\%)$ \\
Skjelett/bevegelsesapparat & 80 & $(31,5)$ \\
Sirkulasjon/hjerte & 46 & $(18,1)$ \\
Lunge/respirasjonsrelatert & 32 & $(12,6)$ \\
Mage/tarm/urinveier & 24 & $(9,4)$ \\
Slag & 20 & $(7,9)$ \\
Kreft & 17 & $(6,7)$ \\
Diabetes & 8 & $(3,2)$ \\
Nedsatt allmenntilstand & 6 & $(2,4)$ \\
Diverse & 6 & $(2,4)$ \\
Vet ikke & 8 & $(3,2)$ \\
Ikke oppgitt & 7 & $(2,6)$ \\
Sum & 254 & $(100 \%)$ \\
\hline
\end{tabular}

På bakgrunn av pasientenes opplysninger har vi kategorisert deres innleggelsesgrunner i tabell 1. 75 prosent oppga at de i tillegg til problemet de hadde vært innlagt for også hadde andre plager.

Om lag halvparten (56,5 prosent) oppgir problemer med synet, men langt de fleste ( 86 prosent) kan lese avisen. Til tross for at 54 prosent oppgir problemer med hørselen, oppgir langt de fleste (84 prosent) at de, eventuelt med hjelp av høreapparat, uten problemer kan føre samtaler med andre personer og føre telefonsamtaler. Det er ingen signifikant forskjell mellom pasientene som utskrives til henholdsvis sykehjem eller hjem når det gjelder sansetap. Det er imidlertid signifikant flere som uten hjelp kan ringe i telefon blant dem som skrives ut direkte til hjemmet. (Se tabell 2.) 
TABELL 2: Forskjell i funksjonsnivå (etter utskrivelsel for pasienter som utskrives til hjemmet og til sykehjem målt ved kjikvadrattest $\left(x^{2}\right)$

\begin{tabular}{|c|c|c|c|c|}
\hline Funksjon & $\begin{array}{l}\text { Sykehjem } \\
\%(n)\end{array}$ & $\begin{array}{l}\text { Hjem } \\
\%(n)\end{array}$ & $\begin{array}{l}\text { Totalt } \\
\% \text { [n] }\end{array}$ & $\begin{array}{l}\text { Signifikans- } \\
\text { nivå }\left(x^{2}\right]\end{array}$ \\
\hline \multicolumn{5}{|l|}{ Kan gjøre lett husarbeid } \\
\hline $\mathrm{Ja}$ & $16[30]$ & $35[49]$ & $24(79)$ & \\
\hline Nei/Trenger litt hjelp & $84(153)$ & $65(93)$ & $76(246)$ & \\
\hline Sum & $100(183)$ & $100[142]$ & $100(325)$ & 0.001 \\
\hline \multicolumn{5}{|l|}{ Kan gjøre tyngre husarbeid } \\
\hline Ja & 5 [9] & $6(8)$ & $5[17]$ & \\
\hline $\mathrm{Nei} /$ Trenger litt hjelp & $95[174]$ & $94[134]$ & $95[308]$ & \\
\hline Sum & $100(183)$ & $100[142]$ & 100 (325) & 0.876 \\
\hline \multicolumn{5}{|l|}{ Kan handle } \\
\hline Ja & $20[36]$ & $23[32]$ & $21(68)$ & \\
\hline Nei/Trenger litt hjelp & 80 [149] & $77[110]$ & 79 [258) & \\
\hline Sum & 100 (184) & $100\lfloor 142]$ & 100 (326) & 0,635 \\
\hline \multicolumn{5}{|l|}{ Kan kle på seg } \\
\hline Ja & $42(76)$ & $69[98]$ & $54(174)$ & \\
\hline $\mathrm{Nei} /$ Trenger litt hjelp & $58[107]$ & $31[44]$ & $46(151)$ & \\
\hline Sum & $100(183)$ & $100[142]$ & 100 [325] & 0.000 \\
\hline \multicolumn{5}{|l|}{ Kan dusje/vaske seg } \\
\hline $\mathrm{Ja}$ & $23(43)$ & $39[56]$ & $30[99]$ & \\
\hline Nei/Trenger litt hjelp & 77 (141) & $61(86)$ & 70 [227] & \\
\hline Sum & $100[184]$ & $100[142]$ & $100(326)$ & 0.000 \\
\hline \multicolumn{5}{|l|}{ Kan flytte seg fra seng til stol } \\
\hline Ja & $55(101)$ & $80[113]$ & 66 (214) & \\
\hline Nei/Trenger litt hjelp & $45[83]$ & $20\lfloor 29]$ & 34 [112] & \\
\hline Sum & $100(184)$ & $100[142]$ & $100[326]$ & 0.000 \\
\hline \multicolumn{5}{|l|}{ Kan spise oppskåret mat } \\
\hline Ja & $91[167]$ & $96(136)$ & $93(303)$ & \\
\hline Trenger litt hjelp & $9(16)$ & $4(6)$ & $7[22]$ & \\
\hline Sum & $100 \mid 183)$ & $100[142]$ & 100 [325] & 0.222 \\
\hline \multicolumn{5}{|c|}{ Kan uten problemer lese teksten $i$ en avis } \\
\hline Ja (evt med hjelpemidler) & $86[156]$ & $85[119]$ & $86(275)$ & \\
\hline $\mathrm{Nei}$ & $14(25)$ & $15(21)$ & $14[46]$ & \\
\hline Sum & $100(181)$ & $100[140]$ & 100 [321] & 0.763 \\
\hline \multicolumn{5}{|c|}{ Kan uten problemer føre en samtale med en annen person } \\
\hline Ja levt med høreapparat] & $84[153]$ & $84[118]$ & 84 [271] & \\
\hline Nei & $16|30|$ & $16[22]$ & $16[52]$ & \\
\hline Sum & $100[183]$ & $100[140]$ & 100 [323] & 0,869 \\
\hline \multicolumn{5}{|l|}{ Kan ringe i telefonen } \\
\hline Ja & 70 [128] & $88[123]$ & 78 [251] & \\
\hline Trenger hjelp/nei & 30 [54] & $12(17)$ & 22(71) & \\
\hline Sum & 100 [182] & $100[140]$ & 100 [322] & 0.001 \\
\hline
\end{tabular}

Det er forskjell på funksjonsnivået til de pasientene som ble overført til sykehjem og de som ble utskrevet til hjemmet. Som tabell 2 viser, har de aller fleste pasienter relativt nedsatt funksjonsnivå ved intervjutidspunktet (gjennomsnittlig 16 dager etter utskrivelsen). Analysen av ADL-funksjoner (som å kunne kle seg, vaske seg og forflytte seg fra seng til stol) viser at pasientene som utskrives til hjemmet har signifikant bedre funksjonsnivå enn de som overføres til sykehjemmet. Når det gjelder IADL-funksjoner er det signifikant forskjell når det gjelder evne til å gjøre lett husarbeid, mens tyngre husarbeid og handle ikke viser samme forskjell. Evnen er sterkt nedsatt i begge grupper. 
Hvor godt erfarer pasienten at sykehuset forbereder dem til utskrivelse?

\section{Informasjon}

To av tre sa at de ikke hadde fått den informasjonen de trengte om sykdommen sin da de ble utskrevet fra sykehuset. Tre av fire oppga at de ikke hadde fått den informasjonen de trengte om hva de kunne og ikke kunne gjøre etter utskrivelsen. Av dem det var aktuelt for, syntes bare hver femte informant (19,6 prosent) at de hadde fått den opplæringen de trengte om sårstell, øvelser de skulle gjøre og om kosthold og så videre.

I det følgende gir vi noen eksempler på kommentarer som kan illustrere bakgrunnen for respondentenes avkrysninger i spørreskjemaet. Vi finner kommentarer som er svært positive: «Legen fortalte ting hele tiden, hun var fryktelig $s \varnothing t$. Så fikk jeg et papir hvor det sto hva som hadde skjedd under oppholdet». Men vi finner også kritiske kommentarer, særlig til mangler i informasjonen om nye medikamenter: «Legen skrev ut hostemedisin - Cosylan - som gjorde meg forvirret. Fikk ingen informasjon om at jeg kunne bli det» eller «Fikk ingen informasjon om bivirkninger. Har hatt bivirkninger tror jeg: tissing om natta og hard avføring. Har sterkt ubehag ved dette». Noen pasienter oppga at de hadde fått informasjon, men at det var vanskelig å huske den: «Jeg var så slapp og dårlig så jeg husket ikke noe av hva han sa». 140 pasienter svarte på spørsmålet om hvordan informasjon ble gitt, og av disse var det 71 prosent av pasientene som oppga at informasjonen bare var gitt muntlig, og ikke også skriftlig. Det er 37 prosent av pasientene som sier de ville ha foretrukket å få informasjon sammen med pårørende, for eksempel fordi: «Det er ting du fort kan misforstå eller glemme når en er syk, og jeg hører jo litt dårlig». Om lag halvparten av pasientene (48 prosent) oppga at de overhodet ikke var blitt spurt om de $\varnothing$ nsket å ha sine pårørende med under informasjon. Hver fjerde pasient (24,8 prosent) oppga å ha fått informasjon sammen med pårørende. Noen av respondentene stilte spørsmål om helsepersonellets syn på eldre var et hinder for at de fikk tilstrekkelig informasjon: «Jeg fikk informasjon i egen samtale om operasjonen. Men jeg fikk ingen informasjon om medisiner, så jeg vet ikke hva slags medisiner jeg tar. Kanskje de (sykehuspersonalet) tror at jeg ikke forstår hva som blir sagt når jeg er så gammel?». 
TABELL 3: Pasientenes erfaringer med informasjon

Dimensjon av informasjon

Da du ble utskrevet, hadde du fătt den informasjonen

du trengte om sykdommen din?

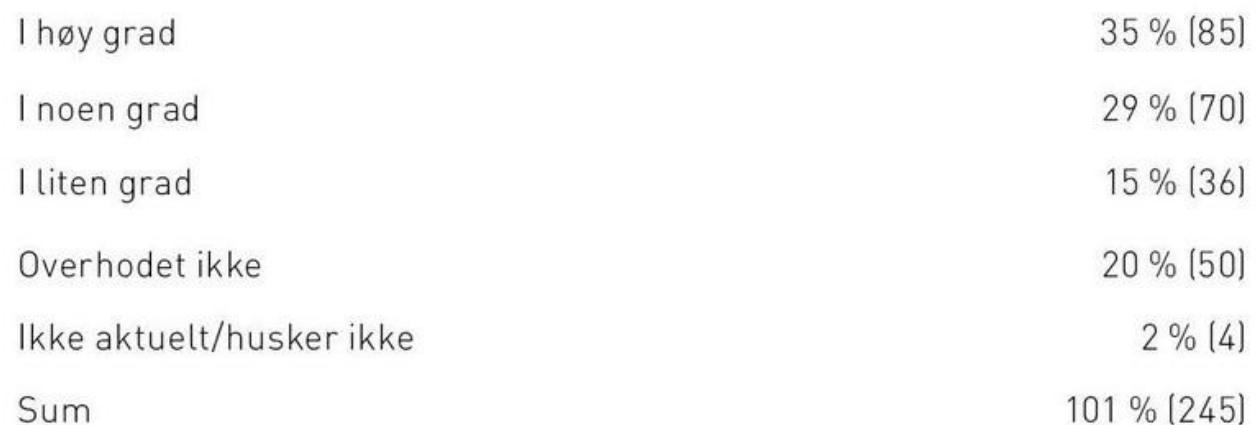

Da du ble utskrevet, hadde du fått den informasjonen du trengte om hva du kunne/ikke kunne gjøre etter utskrivelsen?

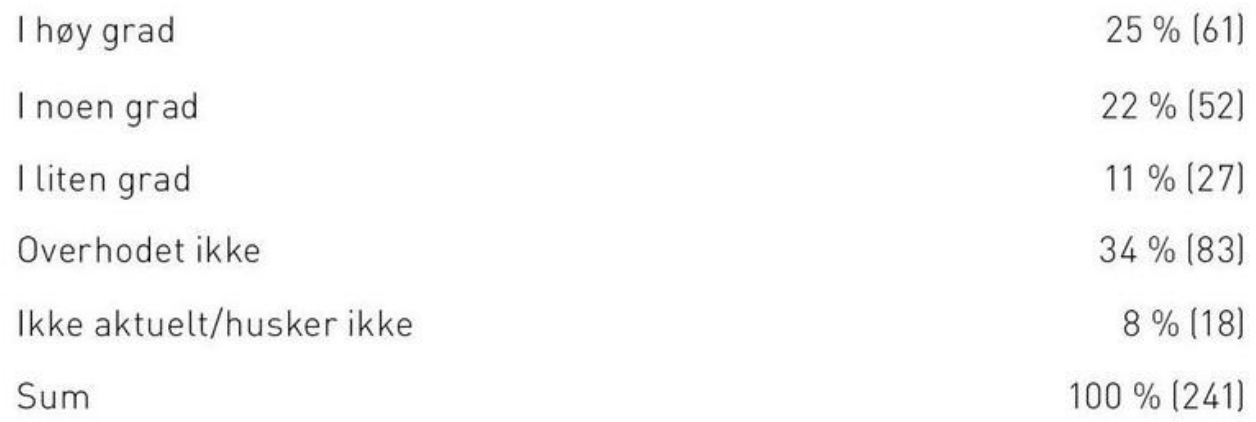

Da du ble utskrevet, hadde du fått den opplæringen du trengte (om sårstell, øvelser, kosthold m.m.)?

I høy grad

I noen grad

$4 \%(9)$

I liten grad

$4 \%(10)$

Overhodet ikke

$11 \%(26)$

Ikke aktuelt

$77 \%(183)$

Sum

$101 \%$ [239]

Da du ble utskrevet, hadde du fått vite det du trengte om virkninger og bivirkninger av medisinene dine?
I høy grad
$12 \%(29)$
I noen grad
$13 \%$ [31]
I liten grad
$16 \%(37)$
Overhodet ikke
$44 \%(104)$
Ikke aktuelt
$16 \%(38)$
Sum
$101 \%$ (239) 


\section{Medvirkning}

Pasientene $\varnothing$ nsket medvirkning. Tydeligst var pasientenes $\varnothing$ nske om å bli hørt knyttet til innflytelse på hvordan praktiske problemer skal løses. Syv av ti ønsket innflytelse, men nesten like mange (64 prosent) opplevde det som viktig å ha innflytelse på utreisetidspunktet. (Se tabell 4.)

TABELL 4: Pasientenes erfaring med medvirkning

\section{Dimensjon av medvirkning}

Hvor viktig var det for deg å ha innflytelse på når du skulle reise?
I høy grad
$39,0(92)$
I noen grad
$25,4(60)$
I liten grad
$20,3(48)$
Overhodet ikke
Sum
$100(236)$

Hvor viktig er det for deg å ha innflytelse på hvordan praktiske problemer skulle løses?

I høy grad

$51,1(118)$

I noen grad

$19,5(45)$

I liten grad

Overhodet ikke

Sum

$100(231)$

Fikk du fortalt personalet det du selv mente var viktig for å klare deg bra hjemme?*

I høy grad

I noen grad

I liten grad

Overhodet ikke

Sum

Fikk du fortalt personalet det du selv mente var viktig i forbindelse med utskrivningen hit?**

I høy grad

I noen grad

I liten grad

Overhodet ikke

Erfarte du at dine meninger ble tatt hensyn til? 
I liten grad

*Spørsmålet er bare stilt til de som utskrives til hjemmet ( $N=142$ )

** Spørsmålet er bare stilt til de som utskrives til sykehjem ( $N=188$ ]

Tabellen viser at $\varnothing$ nsket om samarbeid og innflytelse ikke kan sies å bli innfridd for de fleste, og 43 prosent oppgir at de overhodet ikke fikk fortalt personalet hva de selv mente var viktig for at de skulle kunne klare seg etter utskrivelse. Det er imidlertid ikke til å komme fra at medvirkning krever at pasienten har krefter til en relativt aktiv rolle, og manglende ressurser beskrives av flere: «Jeg hadde ingen meninger for jeg hadde fått så mye medisiner så jeg ble litt sløv og rar». Data viser at pasientgruppen er svært variert. Noen kommentarer viser pasienter som framstiller seg som fullt ut i stand til å ivareta seg selv og egne interesser: «Det var kanskje noe med dialogen med legene. De hadde så liten tid. Men jeg kan si fra, jeg. Det er bra det, vet du!». Men andre framstår som sårbare: «Ble ikke inkludert i samtaler. Det gikk mellom leger og personalet».

\section{Selve utskrivelsen}

Hver tiende pasient oppga å ha hatt en utskrivingssamtale før de reiste fra sykehuset. (Se tabell 5.) 
TABELL 5: Pasientenes erfaringer med selve utskrivningen

\section{Dimensjon}

Var det noen utskrivingssamtale?

$\mathrm{Ja}$

$10 \%(22)$

Nei

$90 \%(197)$

Sum

$100 \%(219)$

Var det avtalt at noen skulle være hos deg da kom hjem landre enn ev. ektefelle/samboer)?*

$\mathrm{Ja}$

$24,6 \%(62)$

$\mathrm{Nei}$

$20,6 \%(52)$

Vet ikke

$1,6 \%(4)$

Ikke aktuelt

$53,2 \%(134)$

Sum

$100 \%(252)$

Var det noen hos deg da kom hjem?*

Ikke aktuelt å ha noen der, jeg klarer meg selv

$10.6 \%(13)$

Nei, jeg kom til tomt hus

$15,4 \%(19)$

Ja, pårørende var der

$57,7 \%(71)$

Ja, hjemmetjenesten var der

$12,2 \%(15)$

Noen andre var der

$4,1 \%(5)$

Sum

$100 \%(123)$

Er det tilbudet du mottar nå det du ønsket deg?

Ja, i høy grad

$72,0 \%(172)$

I noen grad

$17,5 \%(42)$

I liten grad

$8,0 \%(19)$

Overhodet ikke

$2,5 \%(6)$

Sum

$100 \%(240)$

* Spørsmålet er bare stilt til de som ble utskrevet til hjemmet ( $N=142$ ) 
De som kommenterte utskrivningssamtalen ga en nøktern beskrivelse av hvordan den hadde forløpt: «Hun fra bydelen førte ordet. Vanskelig å vite hvordan det ville bli å komme hjem. Det var mekanisk, gjorde det de skulle», eller «Det var ingen diskusjon. Det var: 〈Nå skal du hjem, og du får hjelp〉. Ingen diskusjon». Men det er også mer positive erfaringer, om ikke med selve utskrivningsm øtet, så i alle fall med resultatene av det: «De hadde nok hørt på meg. Da jeg kom hjem, begynte hjemmesykepleien å komme to ganger daglig. Jeg visste det ikke før jeg kom hjem».

Selve utskrivelsen blir erfart og beskrevet ulikt: «Jeg hadde ikke fått beskjed om hva som feilte meg, så det kom brått på. De tok sengene våre om morgenen, måtte sitte på stol til klokka 17 og vente på drosjen. Det var fælt.» Noen av respondentene ga uttrykk for at utskrivningsprosessen var vanskelig: «Jeg var ikke forberedt på hvordan det skulle bli da jeg ble fratatt surstoffet. Jeg ble mye dårligere da jeg kom hjem». Andre igjen ga uttrykk for at det gikk greit: «Jeg er noe svimmel, men ellers ok. Må godta at ting tar lengre tid, og at jeg har blitt avhengig av hjelp».

Vi spurte pasientene hvordan de hadde hatt det etter at de kom hjem eller til sykehjemmet. Av dem som var skrevet ut direkte til hjemmet svarte 54 prosent at de hadde hatt det bra og tilsvarende tall for dem som var skrevet ut til sykehjemmet var 58 prosent. Som tabell 5 viser, oppga nærmere halvparten av dem det var aktuelt for at sykehuset ikke hadde gjort avtale med noen om å være til stede da pasienten kom hjem fra sykehuset. Av dem som var utskrevet direkte til hjemmet, oppga 15 prosent at de kom til tomt hus. De pasientene som kom til tomt hus beskriver dette som svært vanskelig: «Jeg følte meg så ensom og forlatt. Hadde en drøm om at hjemmesykepleien var der og hadde satt på kaffen». En annen sier: «Det var ingen som var der. Ingen kom og sa velkommen hjem. Postkassen var full av post. Til slutt kom hjemmehjelpen og hjalp meg i seng da». Eller: «Det var trist. Tenkte: <Håper noen kommer og rer opp sengen min〉. Satt fra fire om ettermiddagen til langt på kveld og ventet». Selv om det var variasjoner, formidlet respondentene at mange opplevde mye usikkerhet knyttet til utskrivning og oppga at det ikke alltid var forståelse for dette: «Det var liksom ikke noe problem. Du skal få komme hjem - du får hjelp - god tur hjem. Litt sjokk å plutselig få beskjed. Jeg syntes det var verre enn jeg hadde trodd. Det ble mye angst». 


\section{Diskusjon}

Data viser at pasienter på 80 år og eldre har nedsatt funksjon ved utskrivelsen fra sykehus. Man kan se selvrapportert funksjonsnivå på to måter. Enten kan man hevde at de tegner et relativt positivt bilde, pasientenes alder tatt i betraktning, når man tenker på at de ble intervjuet kort tid etter et sykehusopphold. Eller man kan hevde at når 20 prosent av pasientene som sendes hjem og 45 prosent av de som skrives ut til sykehjem, trenger hjelp til å forflytte seg fra seng til stol ved intervjutidspunkt 16 dager etter utskrivelse, viser dette en pasientgruppe som er avhengig av betydelig assistanse. Spesielt har de som skrives ut til hjemmet behov for god forberedelse og tilrettelegging før utskrivning.

Pasientenes gjennomsnittlige liggetid var $12 \mathrm{~d} \varnothing$ gn. Dette er langt mer enn gjennomsnittet for aldersgruppen Statistisk sentralbyrå oppgir, som er seks og et halvt døgn (16). Noe av forklaringen på den store forskjellen kan være at vi kun inkluderte pasienter som hadde vært innlagt minimum to døgn og at et par av pasientene i materialet hadde ekstremt lange liggetider (median var 9). En annen viktig årsak til den lange liggetiden kan være at denne gruppen utgjør de mest skrøpelige eldre pasientene, de som trenger kommunale tjenester etter utskrivning. De trenger trolig lengre tid på å komme seg, og noen av dem kan også ha fått et forlenget opphold i påvente av at tjenestene i kommunen skulle legges til rette.

Utskrivingsprosesser er vanskelige for alle pasienter som har vært innlagt for alvorlige lidelser (2-11). Våre data gir likevel ikke grunnlag for å framstille den eldste sykehuspasientgruppen som ensartet og hjelpeløs. Like fullt er antakelig utfordringene store. Dette gjelder særlig de aller eldste, som har større hjelpebehov enn de yngre og som i tillegg til den aktuelle diagnosen også har andre helseproblemer. 
Det er enighet om viktigheten av at pasienter møter en helhetlig helsetjeneste som er godt samordnet og preget av kontinuitet, uansett hvem som har ansvaret for de enkelte deltjenestene. Særlig viktig er dette for eldre pasienter med langvarige og sammensatte behov. Opplæring av pasienter og pårørende ble i 2001 definert som én av sykehusets fire lovpålagte oppgaver (Lov om spesialisthelsetjenesten, § 3.8). Pasientenes erfaringer, slik de uttrykkes i denne unders $\varnothing$ kelsen, indikerer at sykehusene ikke fyller sine forpliktelser på dette området i tilstrekkelig grad. Både pasientenes svar på de preformulerte spørsmålene og de frie kommentarene deres, indikerer at de eldre selv ikke erfarer at sykehusene forbereder dem i tilstrekkelige grad, verken for utskrivning til hjemmet eller til sykehjem. Respondentene oppga mangler i både medvirkning, informasjon og opplæring.

Tre av fire pasienter oppga at de var tilfredse med tilbudet de fikk etter utskrivelsen, uavhengig av om de var i sykehjem eller hjemme, noe som indikerer at pasientene har fått den hjelpen de trenger etter utskrivelsen. Dette kan trolig i mange tilfeller kompensere for det pasientene oppgir som manglende forberedelse til utskrivelse. Likevel, selv om familien, hjemmetjenesten og sykehjemmet sørger for at det som oftest ender godt, gjenstår altså inntrykket av at sykehuset ikke fyller sin del av det «sømløse pasientforløpet».

I Sverige er utskrivningssamtaler lovpålagt som et tiltak for å bedre samhandling mellom sykehus og kommunale tjenester (17). Av våre informanter oppga svært få at de har hatt noen utskrivningssamtale. Pasientenes kommentarer i vårt materiale indikerer at utskrivningssamtaler ikke automatisk fører til at pasientenes ønsker og behov trekkes inn, men at slike samtaler kan bli svært «mekaniske» og i liten grad trekker pasienten med i planleggingen. Dette er også vist gjennom studier av utskrivningssamtaler i Sverige (17).

Vi ser et potensial for forbedringer. Utskrivningssamtaler kan være ett viktig tiltak, men man må i så fall skape rammer for samtalen som tilrettelegger for at de eldre kan være aktivt medvirkende. Informasjon må ikke kun gis muntlig, men alltid også skriftlig. Informasjon kan og gis i møter der også pårørende deltar, dersom pasienten ønsker det. Man bør også sikre at det blir gjort en eksplisitt vurdering av om pasienten trenger noen der når han eller hun kommer hjem. Og når det er tilfelle må man gjøre klare avtaler om hvem som skal være til stede og om hvilke hjelpetjenester pasienten skal få fra kommunehelse-tjenesten ved hjemkomst. 
I dette materialet blir kun 43 prosent utskrevet direkte til hjemmet. Tallene underestimerer imidlertid andelen som til slutt kommer hjem, for mange av de pasientene som utskrives til sykehjem skal bare ha et korttidsopphold med etterbehandling og rehabilitering før de sendes hjem. Vi kjenner imidlertid ikke det videre boforløpet til de som ble utskrevet til sykehjem.

I denne studien har vi kun analysert data fra den ene parten i hjelperelasjonen. Respondentene kan ha glemt den informasjonen og opplæringen som ble gitt og skriftlig informasjon kan ha blitt forlagt. Informasjon til eldre sykehuspasienter kan være krevende, men ansvaret for at informasjonen når fram, hviler likevel på leger og sykepleiere.

Vi kjenner ikke til noen undersøkelse som har innhentet et tilsvarende stort antall av såpass gamle pasienters erfaringer med utskrivningsprosessen. Kanskje man anser det som for krevende å innhente erfaringene til en gruppe som er så skrøpelig og helsemessig ustabile som gamle, nyutskrevne pasienter? Pasientene som har deltatt i unders $\varnothing$ kelsen er ikke representative for alle pasienter som overføres fra sykehus til kommunale omsorgstjenester. Det er likevel verdt å merke seg at våre respondenter hadde klare meninger og preferanser. I motsetning til enkelte utenlandske unders $\varnothing$ kelsers informanter $(18,19)$ ga de klart uttrykk for at de ønsket å bli hørt, både under sykehusoppholdet og etter hjemkomsten. Også de eldste sykehuspasientene framstår som en viktig kilde til innsikter som er relevante for kvalitetsforbedringer.

\section{Referanser}

1. Samdata Sykehus 2008. Sintef helse, Trondheim 2008.

2. Garcia-Caballos M, Ramos-Diaz F, Jimenez-Moleon JJ et al. Drug-related problems in older people after hospital discharge and interventions to reduce them. Age Ageing 2010; 39: 430-6.

3. Wolinsky FD, Bentler SE, Liu L et al. Recent hospitalization and the risk of hip fracture among older Americans. J Gerontol A Biol Sci Med Sci doi:10.1093/gerona/glno27

4. Wetherell, JL, Birchler GD, Ramsdell J et al. Screening for generalized anxiety disorder in geriatric primary care patients. Int J Ger Psych 2007; 22:115-23. 
5. Miller JF, Piacentine LB, Weiss M. Coping difficulties after hospitalisation. Clin Nurs Res 2008; 17: 278-96.

6. Grimmer K, Moss J, Falco J. Experiences of elderly patients regarding independent community living after discharge from hospital: a longitudinal study. Int J Qual Health Care 2004; 16:465-72.

7. Kalseth B, Midttun L, Paulsen B et al. Utviklingstrekk i kommunehelsetjenesten og spesialisthelsetjenesten oppgaveutvikling og samspill. Rapport STF78 A045018. Trondheim: Sintef Helse, 2004.

8. Forster AJ, Clark HD, Menard A et al. Adverse events among medical patients after discharge from hospital. CMAJ 2004; 170: 345-9.

9. Lanièce I, Couturier P, Drame $\mathrm{M}$ et al. Incidence and main factors associated with early unplanned hospital readmission among French medical inpatients aged 75 and over admitted through emergency units. Age Ageing 2008; 37: 416-22.

10. Sheppard S, Doll H, Angus RM et al. Avoiding hospital admission through provision of hospital care at home: a systematic review and meta-analysis of individual patient data. Can Med Assoc J 2009; 180: 175-82.

11. Marengoni A, Aguero-Torres H, Timpini A et al. Rehabilitation and nursing home admission after hospitalization in acute geriatric patients. J Am Med Dir Assoc 2008; 9: 265-70.

12. Foss C, Askautrud M. Measuring the participation of elderly patients in the discharge process from hospital: A critical review of existing instruments. Scand J Car Sci 2010; $24 ; 46-55$.

13. Katz, S \& Apkom, CA. (1976). A Measure of Primary Sociobiological Functions. International Journal of Health Services, 6, 3, 493-507.

14. Lawton, MP \& Brody, EM. Assessment of older people: Self-maintaining and instrumental activities of daily living. The Gerontologist, 1969; 9: 179-86.

15. Streiner DL, Norman GR. Health measurement scales - a practical guide to their development and use. 3 rd ed. Oxford: Oxford University Press: 2003. 
16. Statistisk årbok 2010.

http://www.ssb.no/emner/03/O2/pasient/tab-2010-04-20-

o6.html.

17. Efraimsson E, Sandman PO, Rasmussen BH. 'They were talking about me' - elderly women's experiences of taking part in a discharge planning conference. Scand J Car Sci 2006; 20: 68-78.

18. Deber RB, Kraetschmer N, Urowitz S et al. Do people want to be autonomous patients? Preferred roles in treatment decision-making in several patient populations. Health Expect 2007; 10: 248-58.

19. Bastiaens H, Royen VP, Pavlic DR et al. Older people's preferences for involvement in their own care: A qualitative study in primary health care in 11 European countries. Patient Educ Couns 2007; 68:33-42. 